\author{
Dariya Nastas \\ Researcher of IT in Education Laboratory \\ Borys Grinchenko Kyiv University, Kyiv, Ukraine \\ d.nastas@kubg.edu.ua \\ ORCID: 0000-0002-9008-8100
}

\title{
ANALYSIS OF THE EXPERIENCE OF THE COUNTRIES OF EASTERN ASIA IN PREPARATION OF FUTURE PRIMARY SCHOOL TEACHERS BY THE IMPLEMENTATION OF DIGITAL TECHNOLOGIES
}

\begin{abstract}
Digital and cloud-oriented technologies gained extremely powerful traction, Big Data and Web technologies are widely used, artificial intelligence is becoming popular as well as the Internet of things, smartphones and other devices have become an integral part of living in civilized society. Prompt digitalization predetermined the situation when learning is conducted spontaneously and informally. In today's realities educational process has to transform quickly and support gaining digital competence by all the participants. It is essential to follow the rules of secure and effective interaction with digital content, form media culture and media information literacy. To overcome challenges that appear in digital era it is necessary to provide high quality preparation of future teachers, that is why our aim was to research and analyze peculiarities of educational process of higher educational institutions of countries which have got significant gains in the field of creation and dissemination of the most modern IT technologies. The article analyzes the educational process of preparation of future elementary school teachers in East Asian countries, namely: South Korea, Japan, China (describes the levels of preparation in the higher education institution (HEI), specifies the peculiarities of the educational program and lists the educational goals that a future elementary teacher should achieve). It provides information on a study initiated and conducted by theThe Republic of Korean Research Foundation and outlines basic ideas for SMART education in understanding South Korean counterparts. Found out how future primary school teachers inThe Republic of Korea are trained in six core subjects with a combination of digital literacy to be taught in junior high. The vector of Japan's higher education reform is presented, which aims at developing conceptually new approaches to the organization of the educational space with a combination of classical pedagogy and IT, as well as information on the certification features of future and current teachers. The article focuses on educational innovations (interaction between IT and education), outlined by President Xi Jinping. The list of qualities that a Chinese teacher should possess in the 21 st century is given.
\end{abstract}

Keywords: higher education institution (HEI); preparation of future teachers; higher education in East Asia; digital technologies; digital competence of the teacher

Formulation and justification of relevance. The world we live in is rapidly changing and education is undergoing and reflecting these changes. The growth in the use of digital technology in the education sector has been accelerating in recent years, and it looks like further expansion is expected in the future. The development of technology and multimedia, the introduction of new pedagogical teaching methods, offer new ways of teaching and allows the teacher to focus more on creating their own creative and dynamic educational content with digital content. In recent years, the world's leading countries have begun to actively develop a variety of educational programs aimed at developing citizens' digital and multimedia competence. This is due to the fact that the rapid take-up of computer technologies in all spheres of life has led to a simplification of the interface of many software products and now the user becomes an active creator of e-content. Friendly interface, cloud-oriented technology and constant access to a wealth of information drives educators to design their own e-products, so the digital competency of educators plays one of the decisive positions in innovative pedagogy. Ukraine's educational process is increasingly adapting to the EU's educational requirements, shaping international requirements and standards for specialist training, outlining ways for educational change. In order to maximize the professional training of the educator and to promote the positive contributions of digital technologies in the countries of Europe, the design and implementation of digital technologies in the educational process is carried out in 
accordance with the recommendations, protocols, standards and other normative documents adopted internationally. For example, the International Organization for Standardization (ISO) and the International Electrotechnical Commission (IEC) form a specialized standardization system worldwide. National bodies that are members of ISO or IEC participate in the development of international standards through technical committees set up by the appropriate organization to address specific areas of technical activity. In the field of information technology, ISO and IEC have established a joint technical committee ISO / IEC JTC 1 / SC36 - «Information technology - Learning, education, and training» ("STANDARDS BY ISO/IEC JTC 1/SC 36", 2019). The Committee has 43 international standards, which have already been published and have a number of others that are under constant work to update the content and implementation mechanisms. Another example of activities aimed at improving the digital competence of educators is the international project «iTEC - Innovative Technologies for an Engaging Classroom», which provides a repurposing of computer-aided teaching and learning processes. Between 2010 and 2014, educational tools and resources were tested on over 50,000 students in 2624 classrooms in 20 European countries ("iTEC classrooom pilots: final evaluation results", 2014). Recognizing that higher education of prospective primary school teachers in EU countries has the same nature and structure of organization in terms of unification of requirements, it was interesting for us to analyze the educational trends of countries that are leading in the creation and distribution of digital technologies - East Asian countries.

Analysis of basic research. In order to carry out the analysis of the state of the national education system in East Asia, a number of scholarly works by both domestic and foreign authors were elaborated. We were most interested in the work of such scientists as M.Boenko, N.Borevska, O.Malysheva, V.Luniachek, Daj Rujhua, Cuj Hunhaj, Chzhan Bejbej, Zhan Long, Chzhan Lun, Van Kaj, Shanshan Lu, which reflects the peculiarities of formation, developing and reforming the system of training of future teachers. Also, in the course of our work, we analyzed educational programs for future elementary school teachers on the example of HEI's pedagogical profile, strategic plans of South Korea and Japan for improving the training of future teachers, as well as examined the content of PRC reforms in the educational sphere by developing information technologies.

The main purpose of this study is to analyze the experience of preparing future elementary school teachers on the example of the most developed countries in the field of creation and dissemination of state-of-the-art IT technologies, to identify the peculiarities of the provision of educational services of HEIs and to clarify the role of the state in the implementation of digital technologies.

Presenting main material. South Korea. In South Korea, it is necessary to study three years in high school in order to receive a high school diploma; There are five types of HEIs (except for military and religious institutions) in the country. These include universities, colleges, pedagogical institutes, open and extramural universities. The system of preparation in HEI is carried out according to three levels of preparation: Bachelor degree - 3 years; Master's degree - 3-4 years, at the end of studies students defend the dissertation; doctorate - 4 years. The main language of study at South Korean universities is Korean, but many programs, especially masters programs, are taught in English. Strict curricula do not develop, a large percentage are the disciplines that students choose independently (general science, specialized). The main component of the educational activity is the practical component, students prepare real projects and solve cases, demonstrating the ability to use the theoretical basis in different situations. All schools are technically equipped, have modern multimedia equipment, computer rooms, technological laboratories, high speed internet, etc.

In 1998, 2003 and 2010, the Ministry of Education, Science and Technology of South Korea recognized the best university as a College of Education (사범대학 소개). The purpose of 
the College is to educate leading teachers and faculty who will lead education, related industries and research to achieve such educational goals:

01. Nurture a healthy personality, to support the educational mission and ethics that teachers and educators need.

02. Develop the ability to fully understand and critically reflect educational phenomena from a pedagogical point of view.

03. Develop the ability to understand the processes and stages of expertise related to the field of research.

04. Develop the practical skills needed in the field of education, such as curriculum leadership, student leadership, and administrative skills.

05. Develop creative thinking and digital literacy to cope with educational changes in a future society.

The South Korean Research Foundation analyzes curricula to ensure that they are in line with government-mandated educational goals. Within the framework of the Foundation's activities, research has been conducted (노은희, 신호재, 이재진, 2019), which briefly examines aspects of digital literacy in the curriculum and diagnoses how primary and secondary school teachers recognize and practice digital literacy education. The survey was conducted for 190 teachers and found that the change in the curriculum (2015) is not significant and the question remains how to implement digital literacy in primary school, as this competence is not clear criteria, is realized only in the practical plane, and can be developed on any - what subject. Teachers need to develop students' hands-on skills in the digital environment, from communication to creating their own e-content. In elementary school, a new subject called «Computer and Life» was created, and it was also recommended that the computer and ITrelated tools (teaching and learning in all subjects) should be constantly used in educational activities. In elementary school, the «Computer Letter» discipline was accepted as compulsory educational content. Particular attention is paid to children on content and online safety, ethics and cyber ways.

Since primary school teaching requires a high level of digital competence, there is a need to train highly qualified pedagogical and digital specialists. In order to develop curricula in accordance with the requirements of the present day, it was decided to involve specialists who, on the one hand, represented digital literacy specialists and, on the other, subject teachers. Thus, in the future, primary school teachers should learn the methods of teaching six core subjects of the elementary school with a combination of digital literacy. For the implementation of this strategy, the teaching of future primary school teachers is also carried out with a combination of classical pedagogy and ICT application. For example, the disciplines within the «Korean» unit have the following tasks: effectively present content using the media; understand and apply different reading methods to the media; according to the purpose or theme, select the appropriate content and media for writing the text; search the library or the web for help. While studying the subjects of the Moral block, students are offered the following tasks: express thoughts, feelings, and experiences in light of media characteristics such as video and the Internet; how to cultivate moral sensitivity to various problems in cyberspace; you must know and practice the manners and laws that you must follow in cyberspace; outline the moral grounds and reasons for the moral attitudes and responsibilities required in the digital age. Also, the list of core disciplines includes the block «Information», where there are the following tasks: understand the details of each phase of the information technology system and improve the process of information communication; analyze the impact and importance of information technology and software development on human and society life; Learn how software is applied and understand its impact on our lives; find programs that were used to collect data and organize them into tables or submit using graphs, etc. 
In addition to the paradigm shift in preparing future educators, the The Republic of Korean government is initiating a variety of pedagogical and IT studies. In 2012, a strategic plan for SMART education was developed. SMART (Self-directed, Motivated, Adaptive, Resource enriched, and Technology) education is not just about education with smart devices, it is an educational paradigm and approaches that can offer smart technology combined with traditional education. To implement SMART's educational policies in schools, the South Korean government has developed digital tutorials, online learning resources, and infrastructure systems that allow wireless Internet access. In addition to these hardware and software support, many educators and researchers have developed SMART training models that have been implemented in real-world learning audiences to determine the effectiveness of SMART education. Also, SMART teachers' perceptions studies were conducted, groups with teachers of different categories (future teachers, acting teachers, leading teachers of HEIs) were studied for this purpose. The research focused on teachers' competencies in owning ICT technologies and their use in the classroom. It turned out that since the teaching staff was born in the period before the widespread and widespread use of the Internet and the total use of digital devices and technologies, there is a huge problem with the personal adoption of technology, educators are forced to master technology and to fight the fear of innovation, as their digital-born students are trying and using all digital innovations quickly and with great interest. To overcome the crises arising from the need to combine classical education with technology, the country devotes a great deal of money to IT support for educational institutions and the creation of various programs and projects to enhance the digital competence of educators (Ha, Lee, 2019)

Japan. The preparation of future teachers in Japan is based on the faculties of universities and colleges. The professions of educators are very prestigious and the attitude of the teacher in the country is very respectful, so out of 76 state universities, 54 have pedagogical faculties. In general, $7 \%$ (university-based) and almost 24\% (college-based) of pedagogical education are obtained from the total number of all students of other specialties. The curricula of the higher school of teacher education should be formed according to the system: basic subjects + elective subjects in specialization and compulsory practice in the bases of elementary and secondary education institutions. Based on the demands of society, informatization and the country's high achievements in science and technology since 2003, the Ministry of Education, Sports, Science and Technology of Japan has recognized that the digital competencies of graduates of HEI are relevant and necessary, so the discipline «Informatics» has been sent mandatory and is developing of the following components: practical computer literacy: use of application software (creation and processing of texts, spreadsheets, presentations and work with images); technical literacy: representation of numbers, knowledge and work with the components of the PC, knowledge of the structure of the PC, the role and functional features of software and hardware, operating systems and networks; social studies: the positive and negative effects of PC use in management, business and healthcare; computer crimes and intellectual property (Benderets \& Kartashova, 2014). In addition to the compulsory discipline of Informatics, future elementary school teachers are completely immersed in the digital world during the educational process. Access to educational disciplines, materials, assignments, and the protection of digital content education projects comes through cloud-based technology and online services; active use of various training platforms, including audio and video lessons; access to social media (wikis, blogs, shared writing tools, etc.); self-education through MOOC and more is promoted.

In the course of obtaining pedagogical education, students try to master as much as possible all the competence stipulated by the educational programs, since after graduation they are expected to have very fierce competition and high level of requirements produced by the state and potential employers. Also, the priority areas of school education in Japan are changing, despite the conservative views of citizens, education is one of the driving forces for the development of the state, so the main criterion for choosing a school was the degree of 
introduction of digital technologies in the educational process. The post of elementary school teacher is very carefully selected graduates of HEI during which it is a mandatory requirement to pass an additional exam for certification (basic, special or temporary) from the prefecture of the Board of Education. During the exam, you must successfully pass a theory test and teaching methodology, a core discipline test in a specialization, interview and show how to apply practical skills using both pedagogical techniques and ICT application. To ensure that educators who have been educated before the introduction of digital competency reforms remain competitive, the Ministry of Education of Japan recommends attending a Crash Course (https://thecrashcourse.com/courses) on computer science, as evidenced by the relevant certificate. The quantity and quality of the certificates that a teacher receives influences his / her qualifications and, accordingly, are financially stimulated, which leads to competition and improves the quality of educational services produced by a particular educator and institution in general.

China. The country has a multi-level system of higher education. Teacher training for primary and secondary schools is carried out in the system of pedagogical educational institutions, which includes secondary schools, colleges and institutes of advanced training. There are some benefits for high school graduates entering pedagogical colleges: they can be enrolled without honors. Higher education in China has to be paid for by all students, but most of the undergraduate students are studying for free, a wide system of scholarships is in place, and various undergraduate study and internship programs have been developed.

In China, as in the West, there is a standard three-level training program: bachelor's degree, term of study - 4-5 years. Upon successful completion of this phase, the graduates receive a university degree with a Bachelor's degree; Master's degree, term of study - 2-3 years. Upon successful completion of this stage, the graduates receive a university degree with a master's degree; doctoral studies, term of study - 2-4 years. Upon successful completion of this phase, the graduates receive a university degree with a Doctorate degree. Knowledge control in HEI is carried out only in the examination form. Exams are conducted in writing (in the form of tests) for each subject, which is given approximately two hours. The subjects are divided into compulsory and optional. There are a certain number of pairs assigned to each subject in the curriculum. If a sufficient number of points is earned during the semester, the student is transferred to the next course. In China, a textbook for every subject is common to all, and is only recommended by the Ministry of Education. There are other textbooks, but the basic one is only one. All prospective elementary school teachers are required to complete a course of study. In addition, in the secondary schools and high schools and in pedagogical research institutions, the results of self-study can take the qualifying exam (Malysheva, 2011).

Also, there is a teacher's qualification act in the country, in accordance with the provisions of the qualification act is divided into 7 categories: the qualification act of a teacher in kindergarten, the qualification act of a teacher of primary school, the qualification act of a teacher of a secondary school, the qualification act of a teacher of a secondary vocational school, the qualification act of a teacher-teacher practices in a secondary vocational school and the qualifications act of a teacher of a higher education institution. The state has established an appropriate level of training for teachers of different categories and details who and with what competencies may hold the post of teacher.

In May 2014, the International Educational Informatization Conference was held in Qingdao, Shandong (East China). Chinese President Xi Jinping sent a greeting message to participants, calling for the promotion of educational reform and innovation through the development of information technology. The Head of State noted that China has been making unremitting efforts to promote education informatization, to disseminate high-quality educational resources through IT, and has declared its readiness to expand, with the rest of the world, the platform of international exchange and cooperation, to actively accelerate integration 
and innovation interaction. In order to implement this educational reform, China's HEIs have become a basic tendency to establish relatively independent modules in curricula, which has helped transform the professional education of future educators and gradually ensured the formation of a relatively independent system that is able to adapt to the requirements of society. In the same year, Professor at the University of Shanghai, Chzhan Cze conducted a large-scale study of 16 aspects of student learning in higher education colleges. In addition, the researcher compared students' learning in two different programs: the standard traditional program and online courses and ICT. About $40 \%$ of students studying under the traditional program said they were satisfied with the quality of their studies but would not mind passing the material «once again» in a parallel program (using digital technologies). This confirms the tendency to expand the use of modern digital and multimedia, distance education technologies in the process of personal and professional development of future Chinese teachers (Long, 2018).

Based on the research of scientist Wang Kai, it is possible to formulate a list of qualities that a Chinese teacher of the 21 st century should possess: a teacher must learn all his life; be an experienced diagnostician who has training skills; credible psychologist; specialist in discipline planning; expert in group and team work; instructor in self-study and self-study, as well as a connoisseur of modern education technologies, provider of information resources. According to the author, the development of modern education technologies offers the teacher many ways of transferring knowledge, especially computer and multimedia teaching demonstrates the broad prospects for development. The teacher needs to learn how to master these technologies, he must become a user, distributor and digital expert. The teacher should help the student to find and absorb the necessary information by turning it into knowledge (王凯, 2015).

Conclusions. The conducted research allows to make the following conclusions: 1) the digitalization of society makes it necessary to update the educational process and to rebuild the usual ways of learning taking into account the opportunities of the IT sector; 2) integrate IT at the national, regional and, in most cases, institutional levels in order to effectively develop the digital competence of future primary school teachers in the educational process; 3 ) in the countries of East Asia, digital competence have been an integral part of developing a harmonious and successful personality and have been emerging since childhood; 4) in recent years, educational reforms have necessarily included the development of digital competencies, increased access to the Internet and the provision of IT support to educational institutions at all levels; 5) educational programs are modular, a large percentage of disciplines are variational, and teaching is carried out in a distance form with the involvement of digital content; 6) countries try to support educators as much as possible in their professional development, so at the national level, various ICT-based training programs are initiated. An analysis of the experience of East Asian countries in the preparation of future primary school teachers can be used in reforming teacher education in Ukraine. This study is not exhaustive. We see prospects for further research into developing the content and methods for developing the digital competence of future teachers and existing scientific teaching staff in our country.

\section{REFERENCES}

$\begin{array}{llllllll}\text { Standards by ISO/IEC JTC } & 1 / \mathrm{SC} & 36 & \text { (2019). October } & 18, & 2019\end{array}$ https://www.iso.org/committee/45392/x/catalogue/p/1/u/0/w/0/d/0

iTEC classrooom pilots: final evaluation results (2014). October 18, 2019

http://itec.eun.org/web/guest/evaluation;jsessionid=BD1CBBDEBF30BBCE810255CE5BC3 9280

노은희, 신호재, 이재진 (2019). 초·중학교 교사의 디지털 리터러시 교육에 대한 인식 분석, The Journal of Curriculum and Evaluation, Vol. 22, No. 3, 31-60. October 22, 2019 (in Korean) http://www.kice.re.kr/boardCnts/view.do?boardID=1500201\&boardSeq=5038348\&lev=0\&m $=030202 \&$ searchType $=\mathrm{S} \&$ status $\mathrm{YN}=\mathrm{W} \&$ page $=1 \& \mathrm{~s}=$ kice 
Ha, C. \& Lee, S. (2019). Elementary teachers' beliefs and perspectives related to smart learning in South Korea, Smart Learn. Environ. 6, 3 doi:10.1186/s40561-019-0082-5 . October 22, 2019 (in Korean)

https://slejournal.springeropen.com/articles/10.1186/s40561-019-0082-5

Benderets, N. \& Kartashova, L. (2014). Experience of Information Technologies Teaching to Future Teachers in Japan, Elektronne naukove fakhove vydannia "Narodna osvita", 2(23). October 26, 2019 (in Ukrainian)

https://repository.kristti.com.ua/handle/eiraise/462

Malysheva, O. (2011). Professional and teachers' training to the performance official duties (experience of the PRC). October 30, 2019 (in Ukrainian)

https://www.sworld.com.ua/index.php/ru/pedagogy-psychology-and-sociology-411/theory-

and-methods-of-studying-education-and-training-411/11192-411-0755

Zhan, Long (2018). Trends of development and perspectives of the experience of personal and professional chinese teachers' improvement use in the system of pedagogical education of Ukraine, Zasobi navčal'noj ta naukovo-doslìdnoï roboti, 47. October 30, 2019 (in Ukrainian)

Gladun, M., Nastas, D., \& Spivak, S. (2018). Formation of digital competence of future teachers of elementary school using blended learning and personal learning environment. Open educational e-environment of modern University, (5), 58-65. doi:10.28925/24140325.2018.5.5865. October 20, 2019

http://openedu.kubg.edu.ua/journal/index.php/openedu/article/view/167

王凯 (2015). 教师应具备什么素质 // 第一文库. October 30, 2019 (in Chinese)

http://www.wenku1.com/view/E2C50A299A88C618.html

\title{
АНАЛІЗ ДОСВІДУ КРАЇН СХІДНОЇ АЗІЇ 3 ПІДГОТОВКИ МАЙБУТНІХ УЧТЕЛІВ ПОЧАТКОВОЇ ШКОЛИ ШЛЯХОМ ІМПЛОМЕНТАЦІЇ ЦИФРОВИХ ТЕХНОЛОГІЙ
}

\author{
Настас Дар'я Леонідівна \\ Науковий співробітник НДЛ інформатизації освіти \\ Київський університет імені Бориса Грінченка, Київ, Україна \\ d.nastas@ kubg.edu.ua \\ ORCID: 0000-0002-9008-8100
}

\begin{abstract}
Анотація. Надзвичайно потужного розвитоку набули цифрові та хмаро орієнтовані технології, широко застосовуються BigData та Web-технології, набуває популяризації штучний інтелект та інтернет «розумних речей», смартфони та інші гаджети стали невід'ємною частиною існування у цивілізованому суспільстві. Стрімка диджиталізація зумовила ситуацію, коли навчання відбувається стихійно та неформально. В сучасних реаліях освітній процес має швидко трансформуватись та сприяти набуттю цифрових компетенцій у всіх його учасників. Необхідно дотримуватись правил безпечної та ефективної взаємодії із цифровим контентом, формувати медіакультуру та медіаінформаційну грамотність. Для подолання викликів, які постають у цифрову епоху, неоюхідно забезпечити якісну підготовку майбутніх учителів, тому нашою метою було дослідити та проаналізувати особливості освітнього процесу 3ВО країн як мають значні здобутки у сфері створення та розповсюдження найсучасніших ІТ-технологій. В статті проаналізовано освітній процес підготовки майбутніх учителів початкової школи країн Східної Азії, а саме: Кореї, Японії, Китаю (описано рівні підготовки у ЗВО, вказано на особливості формування освітньої програми та перераховано освітні цілі, які має досягти майбутній учитель початкових класів). Наведено відомості щодо дослідженя, яке ініційовано та проведено Корейським дослідницьким фондом та описано основні ідеї SMART-освіти у розумінні корейських колег. 3'ясовано як здійснюється підготовка майбутніх учителів початкової школи Кореї із шести основних предметів із поєднанням цифрової грамотності, які будуть викладатись у молодшій школі. Представлено вектор реформування вищої освіти Японії, який спрямований на розвиток концептуально нових підходів організації освітнього простору із поєднанням класичної педагогіки та IT, також представлено відомості про особливості сертифікації
\end{abstract}


майбутніх та діючих учителів. У статі приділено увагу освітнім інноваціям (взаємодію між IT і освітою), які було окреслено Головою КНР Сі Цзіньпін. Надано перелік якостей, якими має володіти китайський учитель у XXI столітті.

Ключові слова: ЗВО; підготовка майбутніх учителів; вища освіта Східної Азії; цифрові технології; цифрова компетентність вчителя. 